Indrit Vozga*

Mechanical Engineering Faculty, PUT, Tirana, Albania
Scientific paper

ISSN 0351-9465, E-ISSN 2466-2585

UDC:620.17:66.017

doi: $10.5937 /$ ZasMat1704455V

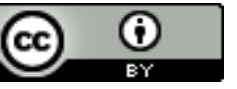

Zastita Materijala 58 (4)

455 - 461 (2017)

\title{
Biological hard materials
}

\begin{abstract}
Using only precursors commonly available in the environment at ambient temperatures evolution has developed materials with complexity and properties which today's engineers can only dream of producing. When examining biological hard materials the inclination is to compare the mechanical properties of biological materials with man made materials and to say man made materials are superior in some ways they are. Biology has never come up with materials as hard as silicon carbide, or as strong as steel, but to make these comparisons is to severely misunderstand the materials present in the natural world. The hard materials biology has produced, each of which while not hard by engineering standards, is incredibly complex and performs its role within the organism better than any synthetic material ever could.
\end{abstract}

Keywords: biological hard materials, mechanical properties, synthetic materials, engineering standards.

\section{INTRODUCTION}

Within the animal kingdom much of the hard tissue produced is part of the skeleton, two primary types of which exist, the endo- and exo- skeleton. Logically the endoskeleton is contained within and the exoskeleton outside the body. Though both types fill the same or a similar biological niche fossil evidence implies that both types of skeletons evolved separately. Endoskeletons consist largely of calcium phosphate, and the primary hard tissue is called cartilage and bone. Exoskeletons on the other hand can consist largely of chitin as in the case of arthropods, or calcium carbonate in the case of mollusks. Silica is also used by a small number of microorganisms as a cell wall and will be discussed later in this paper [1].

Bones in the role of the endoskeleton can be found in vertebrates such as birds, fish, mammals and reptiles. The bones of each class of vertebrate differ in structure, but composition stays roughly constant. Mammalian bones consist of a compact outer layer for mechanical support and a porous or cancellous inner layer filled with marrow for the production of blood cells.

\footnotetext{
*Corresponding author: Indrit Vozga

E-mail: indritvozga@gmail.com

Paper received: 25. 06. 2017.

Paper corrected: 08.09.2017.

Paper accepted: 22.09.2017.

Paper is available on the website:

www.idk.org.rs/journal
}

The bones of birds are similar to those of mammals, though they usually visibly thinner and filled with air to reduce weight. Many reptiles have far fewer veins within their bones than those of mammals and birds due to their much slower metabolism. Amphibians tend to have very simple bones with no veins at all. Bone cells do exist in fish, and while they do form bone they then proceed to die and the cavities are filled with minerals. In the case of sharks and lungfish bone is usually replaced by cartilage [2].

It is beyond the scope of this paper to go into detail on all animal bones, and so for the sake of brevity only human bones will be covered. If an engineer were to design a human body, he would easily be able to point out some required mechanical properties of bones in order for the body to function. First bones need to be strong enough to support the mass of the human body. Secondly they need to be stiff so that they can act as a fulcrum for mussels and allow movement. Evolution has provided a bone material with these constraints in the form of a composite of collagen and mineralized calcium phosphate. In addition in humans and most mammals bones have the added function of a production center for blood cells and as a calcium sink [3].

Bones are not a simple material by any means. At its most basic bone can be said to consist of mineralized calcium phosphate, collagen, and protein, along with small amounts of other materials such as water, and living cells. These 
bone cells are called osteocytes and are responsible for the construction and repair of bone. All of these simple components are arranged within the skeleton in several different ways giving different types of bone with different properties. Bones are all anisotropic and assembled on the micro- or even nano-scale. The outside of bone is called compact bone, and is what people generally think of when they think of bone. Compact bone is dense, though blood vessels still pass through it and its primary purpose is to provide mechanical strength. The thickness of compact bone varies based on location and mechanical need. Cancellous bone is on the interior and is responsible for the production of blood cells. The material that makes up both compact and cancellous bone can be further classified into four basic types, woven bone, lamellar bone, Hauversian systems, and fibrolamellar bone [2].

Woven bone consists of a weave of fibers as fine as $0.1 \mu \mathrm{m}$ arranged with very little long range order. Like the other types of bone woven bone is penetrated by blood vessels, however unlike other types the spaces around the blood vessels are large and interconnected which allows osteocytes to communicate and receive nutrients. Woven bone is somewhat weaker than the other types of bone, and is seen only in places where quick growth is necessary such as in fetuses or on a freshly fractured surface [2].

The second type of bone, called lamellar, takes longer to grow, but has a much more ordered and dense structure. The collagen and calcium phosphate are arranged in sheets, called lamellae, which are roughly $5 \mu \mathrm{m}$ thick. Between sheets there is a layer of calcium phosphate with little collagen. Virtually no out of plane orientation is present which leads to a very isotropic structure which has mechanical consequences which will be discussed later [2].

Haversian systems are formed when blood vessels intentionally erode existing bone in approximately $50 \mu \mathrm{m}$ radius. The formation of a Haversian system is depicted in Figure 1. The cavity is then enclosed in a cement sheath containing virtually no collagen, and then lamellar bone is deposited radially in the cavity until it filled in. This effectively cuts off all cells from the blood vessel. The formation of a Haversian systems leads to the formation of even more Haversian systems, and has a negative effect on the mechanical properties of bone. The reason for the formation of Haversian systems is unknown. Initially most human bone is fibrolamellar, but as aging progresses most of the fibrolamellar bone is replaced with Haversian systems [2].

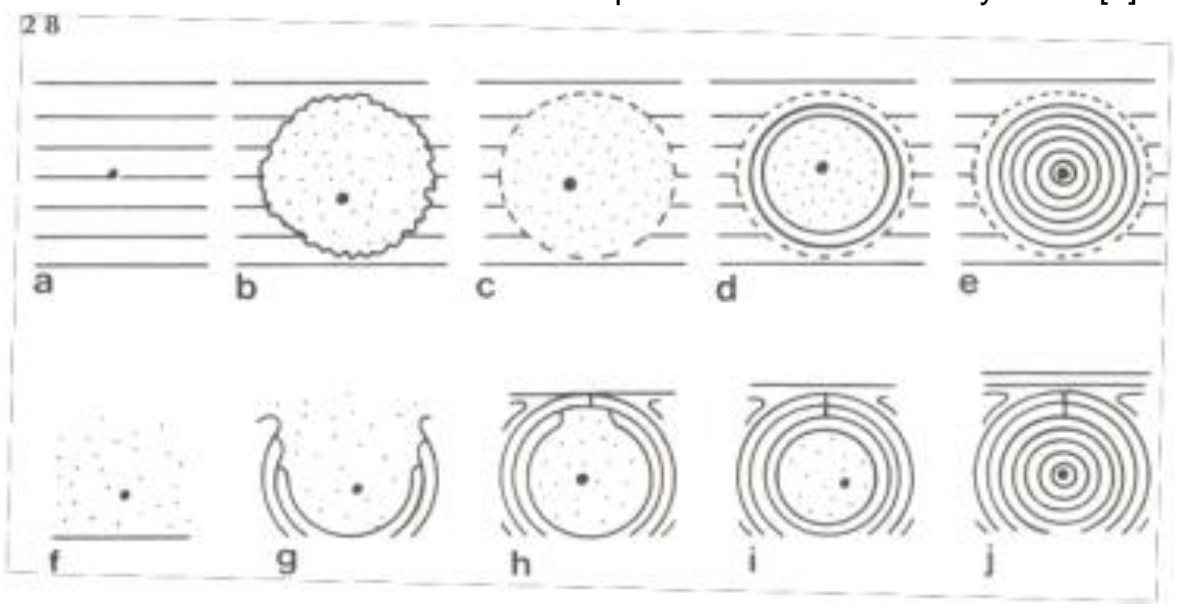

Figure 1. Two ways in which concentric cylinders are formed in bone, shown very schematically, (a-e) the formation of a secondary osteon, or Haversian system, (a) A blood vessel is surrounded by preexisting bone, (fa) Osteoclasts resorb bone around the blood vessel (tissue fluid indicated by dots), (c) The edges of the cavity are neatened off, and a cement sheath (shown by inter rupted line) is laid down, (d) The cavity begins to be filled in by lamellar bone, (e) The mature secondary osteon. Note that the course of the preexisting lamellae is interrupted by the osteon. (1-j) The formation of a primary osteon. This can take place only on a growing surface. The lamellae are not interrupted by the osteon, and there is no cement sheath [2]

Slika 1. Dva načina na koji se koncentrični cilindri formiraju u kosti pokazalni su šematski, (a-e) formiranje sekundarnog osteona ili Haversovog sistema, (a) krvni sud je okružen preostalom koskom, (fa) Osteoklasta resorbuje kost oko krvnog suda (fluidna tkiva su naznačena tačkama), (c) ivice šupljine su sređene, a postavljen je i cementni plašt (prikazan međusobno iskrivljenom linijom), (d) Šupljina počinje da se popunjava lamelarnom koskom, (e) Zreli sekundarni osteon. Imati na umu da je pravac preostale lamele prekinut od strane osteona. (I-j) Formiranje primarnog osteona. Ovo se može desiti samo na rastućoj površini. Lamele ne prekidaju osteon, a nema cementne ploče [2] 


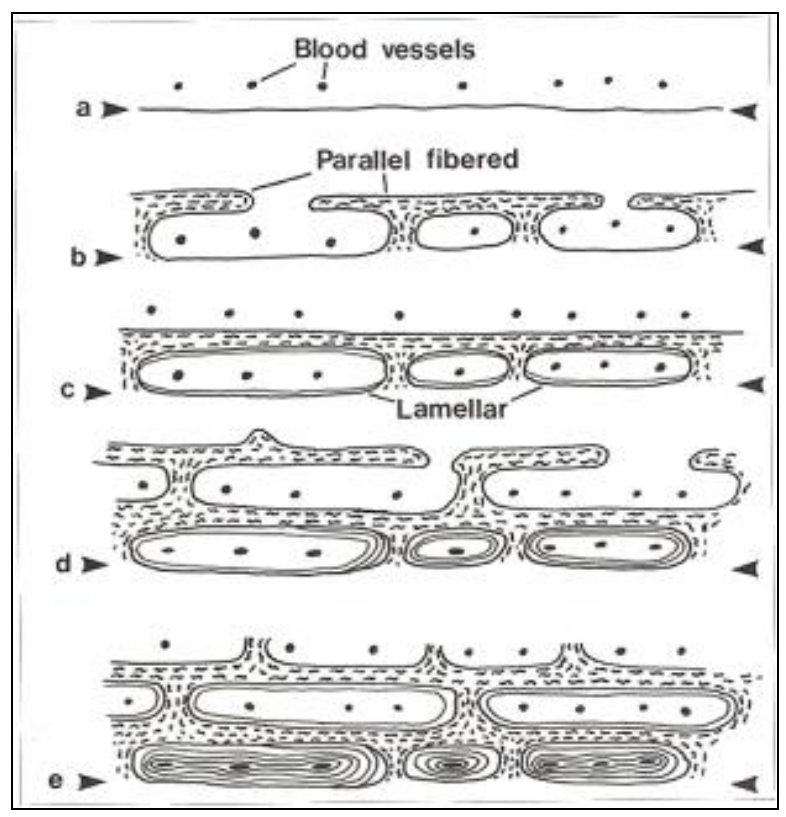

Figure 2. The formation of fibrolamellar bone.

These are cross sections of the outer surface of a rapidly growing bone. The arrowheads show the position of the original surface. Blood vessels are shown by black spots, (a) The original position, (b) Parallel-fibered bone, shown by squiggly lines, grows very quickly to form a scaffolding clear of the original surface, (c) Lamellar bone, shown by fine lines, starts to fill in the cavities left by the parallelfibered bone, (d) As more lamellar bone is laid down, so is another scaffolding of parallel-fibered bone, (e) By the time the first row of cavities is filled in, the outer surface of the bone is far away [2]

Slika 2. Formiranje fibrolamelarne kosti. To su preseci spoljne površine brzo rastućih kostiju. Glave strelica pokazuju položaj originalne površine. Krvni sudovi su prikazani crnim tačkama, (a) Prvobitni položaj, (b) Kosti sa paralelnim vlaknima, koje se prikazuju isprekidanim linijama, raste veoma brzo da

bi se formirao skelet od prvobitne površine, (c) Lamelarna kost, prikazana finim linijama, počinje da popunjava kavitete koje ostavlja paralelno-vlaknasta kost, (d) Kako je postavljeno više lamelarne kosti, tako je i druga skela paralelno-kostna kost, (e) Kada se popuni prvi red šupljina, spoljašnja površina kosti je daleko [2]

The fourth type called fibrolamellar bone is usually found in large mammals and is formed when bones need to grow more quickly than lamellar bone can be formed, but where woven bone alone would not provide enough structural support. To achieve this "scaffolding" of laminellar bone like the one in Figure 2 is constructed and filled in at a later time [2].

On the macro scale these bone types are structured as either compact or cancellous bone. Cancellous bone is present on the interior of bone and consists of interconnected pores in a matrix of approximately $0.1 \mathrm{~mm}$ struts at the very center of bones where little load bearing occurs, to anisotropically arranged plates near the edges when some small mechanical loading may occur. Porosity varies between $100 \%$ and approximately $50 \%$, and the pores are usually filled with marrow. Compact bone forms around the cancellous bone and is more than $50 \%$ dense. In some cases compact bone needs to grow in a location where cancellous bone already exists, in this case the cancellous structure is not destroyed, and new bone is simply wrapped around the struts until most of the porosity is removed. Surprisingly even though compact bone can form from cancellous bone, a sharp transition between the two and not a gradual transition as would be expected is usually observed.

As the main structural element of vertebrates bone needs to be stiff and strong in order to withstand the stresses encountered and give the body a definite structure. The tensile and compressive strengths of bones for humans and cattle in different directions is shown in Table 1. It is important to note that the measurements in the figures were taken at lower stain rates then would be typically encountered in practice, so in living beings bone has a practical strength higher than those shown in the tables.

Unlike brittle materials or metals bone does not exhibit a clean fracture or much plastic deformation, but instead fractures as a fibrous composite. This is unsurprising because it is a structure of mineralized hydroxyapatite in a collagen binder. The benefits of a composite structure are obvious, very brittle bones which present little barrier to crack propagation would fracture to easily, and ductile bones could bend which could add to difficulty in repair [2].

Due to the size of the medical industry and the applicability for bone replacement in humans I will go into some detail on surgical bone replacement. Bones are commonly replaced with metal, ceramic, or donated bone tissue depending on the situation and location of the surgery. Bone replacements need to be biocompatible, corrosion resistant, and have mechanical properties better than or equal to that of natural bone for the best results. All synthetic materials are inferior to a natural bone replacement, however scarcity of natural bone, difficulty in storage, and difficulty in finding pieces of the correct size necessitate the use of synthetics [3]. 


\section{Table 1. Failure Properties of Compact Bone}

Tabela 1. Propustne karakteristike kompaktne kosti

\begin{tabular}{|l|c|c|c|c|c|c|}
\hline \multicolumn{1}{|c|}{ Species Histology } & \multicolumn{2}{c|}{ Man HS } & \multicolumn{2}{c|}{ Cow HS } & \multicolumn{2}{c|}{ Cow FL } \\
\hline Direction of loading relative to long axis & Parallel & Normal & Parallel & Normal & Parallel & Normal \\
\hline Tensile Strength & 148 & 49 & 144 & 46 & 167 & 55 \\
\hline Yield strain & 0.007 & 0.004 & 0.006 & 0.004 & 0.006 & 0.005 \\
\hline Ultimate strain & 0.031 & 0.007 & 0.016 & 0.009 & 0.033 & 0.007 \\
\hline Compressive Strength & 193 & 133 & 254 & 146 & 294 \\
\hline Yield strain & 0.010 & 0.011 & 0.011 & 0.014 & 0.010 \\
\hline Ultimate strain & 0.026 & 0.028 & 0.016 & 0.031 & 0.014 \\
\hline
\end{tabular}

Table 1: All units in MPa.

\section{APPLICATION}

Ceramics are also used in implants. Alumina is useful for its hardness, but tends to jam even when a small amount of particle wear occurs, making it unsuitable except when it is used to slide against a polymer, such as in the case of the femoral head in the hip. Research is being done into the use of carbides an nitrides which combine the mechanical properties of alumina with lower friction. Finally synthetic biocompatible ceramics such as hydroxyapatite can be used as bone filler. These ceramics are porous and have a composition similar to that of natural bone, so they can be colonized by bone cells, which dissolve and rebuild the structure essential turning the implant into living tissue.

Exoskeletons unlike the bone endoskeleton systems discussed tend to be made of calcium carbonate or chitin. Mollusks such as clams and snails use calcium carbonate shells primarily as a means of protection from predation, and crustaceans use calcium carbonate to mineralize their chitin shells. Arthropods on the other hand make their exoskeleton from chitin, which is not as hard as calcium carbonate, but is much tougher.

The shells of mollusks such as clams and mussels consist of a complex crystal structure assembled in patters depending on the animal the shell belongs to, and its environment. At its most basic the shell consists of calcium carbonate crystals bound together in a protein matrix, usually coated be a protein sheet to reduce corrosion [4].

Shells have been observed to form in six unique microstructures, below is an excerpt from Wilbur describing each:

- Nacreous: tabular crystals arranged in laminae or columns as shown in Figure 3.

- Foliated: elongate flattened crystals arranged side-by-side or in overlapping sheets
- Prismatic: parallel polycrystalline elongate prisms enclosed in and organic sheath as shown in Figure 4

- Cross lamellar: tablet-shaped crystals, each composed of parallel rod like elements which, in adjacent crystals run in different directions and which, in alternate crystals run in the same direction as shown in Figure 5

- Spherulitic: spherical structures of elongated crystals radiating from a center

Homogeneous and granular: Taylor et al. (1969) designate homogeneous as a term of convenience for any fine grained structure. The grains may be irregular or rounded and are usually less than $5 \mu \mathrm{m}$ across. Aggregates of larger size are called granular [4].

Often different microstructures are continuous within the same shell, the reasons for the different morphologies is not well understood.

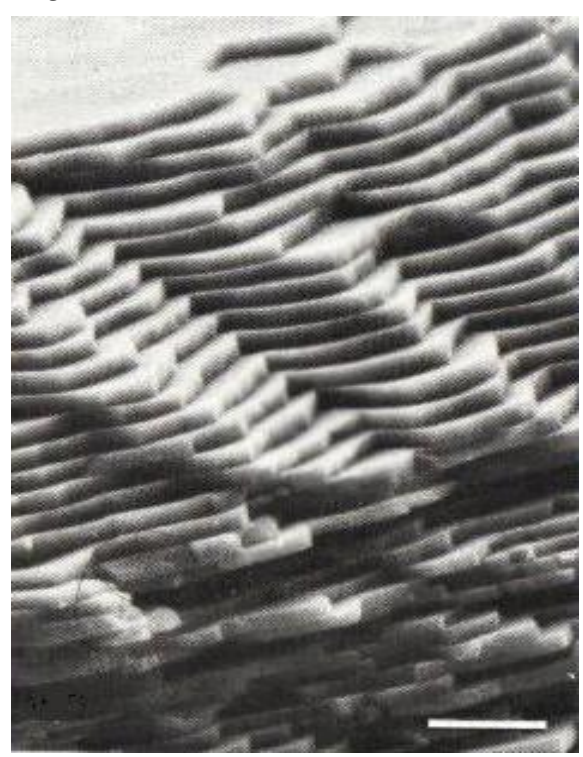

Figure 3. Nacreous shell of Ceukensia demissa. Fracture surface. Bar, 10 $\mathrm{m}$.

Slika 3. Nacreous shell of Ceukensia demissa. Površina preloma. Bar, $10 \mu \mathrm{m}$. 


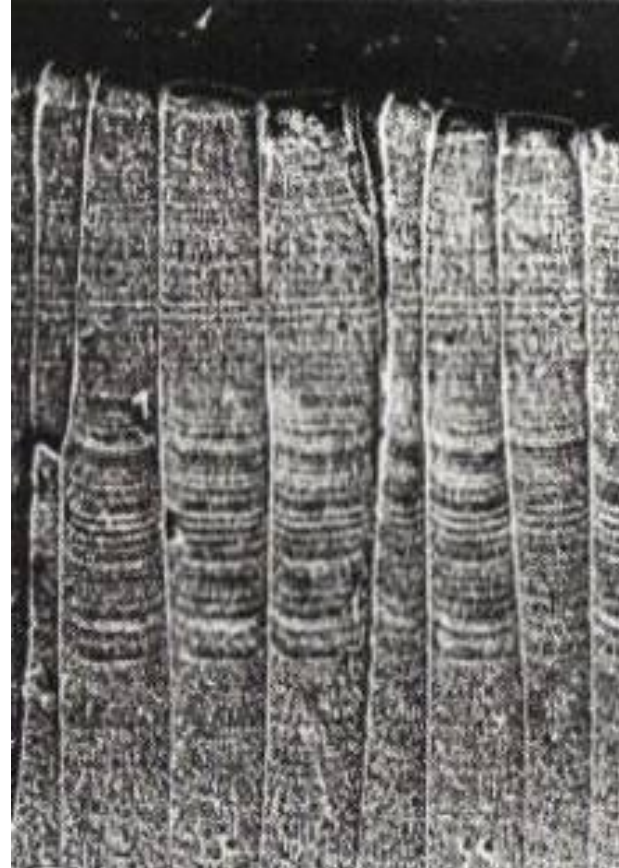

Figure 4. Prismatic shell of Anodonta woodiana. Vertical section of simple prisms. Brief etching after polishing. Bar, $50 \mu \mathrm{m}$

Slika 4. Prismatic shell of Anodonta woodiana. Vertikalni deo jednostavnih prizma. Kratka nagrizanje nakon poliranja. Bar, 50 $\mu \mathrm{m}$

Shell formation first occurs in the extrapallial fluid, which separates the shell and the body of the mollusk. Crystals nucleate in the extrapallial fluid and are then enveloped by a protein matrix which binds the microcrystals together and prevent further growth. The mollusk is capable of changing the microstructure of the shell being layered based on environment in a mechanism which is not understood. Usually the formed microcrystals are either aragonite or calcite, and very rarely vaterite, all of which are forms of calcium carbonate [4].We will now go into detail concerning the formation of nacreous shells. Nacreous shell is not the most common type of shell but due to its beauty in the form of pearl and it structure it is by far the most studied structure and is representative in formation of the other types. In gastropods like snails nacre is formed first with the secretion of the organic matrix and the random deposition of seed crystals on it. More and more crystals are then deposited on the seeds first creating conical stacks of crystals, then when the cones come into contact with each other and continue growing the stacks become polygonal. Occasionally two stacks grow together which improves the fracture resistance of the cell.

The formation of nacre in bivalves such as clams and mussels is slightly different and will not be discussed [5].

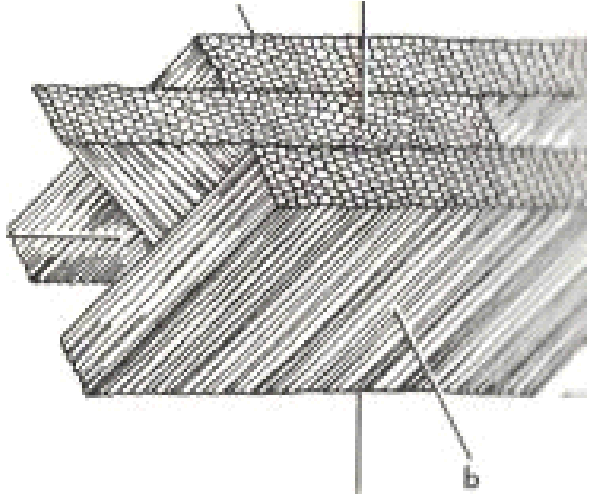

Figure 5. Diagram of cross lamellar structure in polyplacophorans. The three large units are firstorder lamellae (lamels). The smaller units which make up the first-order lamellae are called secondorder lamellae (lamels). a, b, c: Crystallographic axes; $h$, vertical axis of first-order lamella; l, long horizontal axis of a first-order lamella; br, short horizontal axis of a first-order lamella.

Slika 5. Dijagram unakrsne lamelarne strukture $u$ polypla cophorans. Tri velike jedinice su lamele prvog reda (lamele). Manje jedinice koje čine lamele prvog reda nazivaju se lamele drugog reda (lamele).

$a, b, c:$ Kristalografske ose; $h$, vertikalna osovina

lamele prvog reda; I, uga horizontalna osovina lamele prvog reda; br, kratka horizontalna osovina lamele prvog reda.

Anthropoid exoskeletons are not as hard as those of mollusks, but they still warrant consideration. The exoskeleton consists of an epidermis on the inside whose primary function is to excrete the rest of the exoskeleton. Outside of the epidermis is a layer of chitin, a long chain polymer, which is bound together by a cross linked protein which is highly variable in composition depending on species and location [6]. In fact the composite used by arthropods is probably mechanically superior to bone in every respect on a per weight basis, though it requires a significantly more complex development [2].

One biological hard material of particular interest to materials science and nanotechnology is the frustule, or the cell wall of a diatom. Diatoms are microalgae found worldwide in most aqueous environments with a size between $5 \mu \mathrm{m}$ and $5 \mathrm{~mm}$. The shape and size of diatoms varies greatly, however all share a basic structure of two halves of amorphous polymerized silica connected by girdle bands similar to the one shown in Figure 6 [6].

The interesting characteristic of the frustule is that they can contain multiple consistently nanosized features as visible in Figure 7. The knowledge of how to create consistent nanofeatures interests nanolithographers, and the aspects of a timed drug delivery system offered by frustules interests the pharmaceutical industry [7]. 


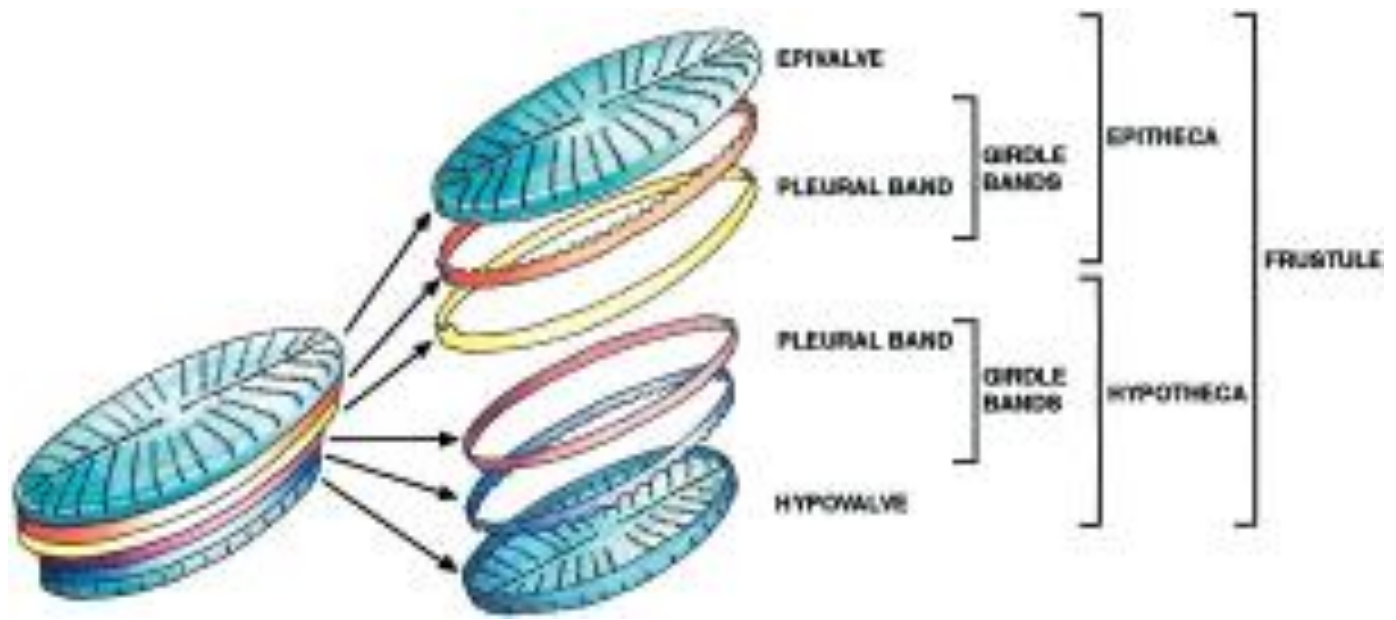

Figure 6. Schematic overview of the siliceous components of diatom cell walls. Drawing by lan Nettleton.

Slika 6. Šematski pregled silikatnih komponenti zidova diatomskih ćelija. Crtež lan Nettleton.

One biological hard material of particular interest to materials science and nanotechnology is the frustule, or the cell wall of a diatom. Diatoms are microalgae found worldwide in most aqueous environments with a size between $5 \mu \mathrm{m}$ and $5 \mathrm{~mm}$. The shape and size of diatoms varies greatly, however all share a basic structure of two halves of amorphous polymerized silica connected by girdle bands similar to the one shown in Figure 6 [6].

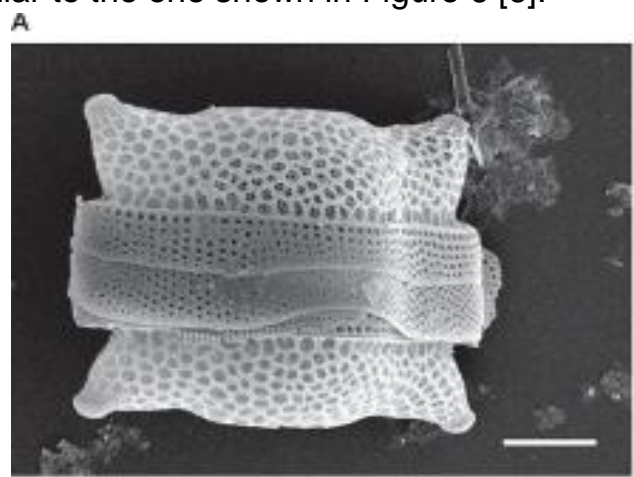

B

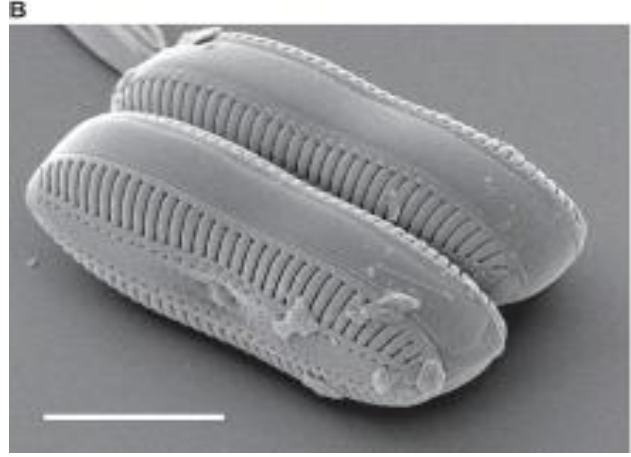

The interesting characteristic of the frustule is that they can contain multiple consistently nanosized features as visible in Figure 7. The knowledge of how to create consistent nanofeatures interests nanolithographers, and the aspects of a timed drug delivery system offered by frustules interests the pharmaceutical industry [7].
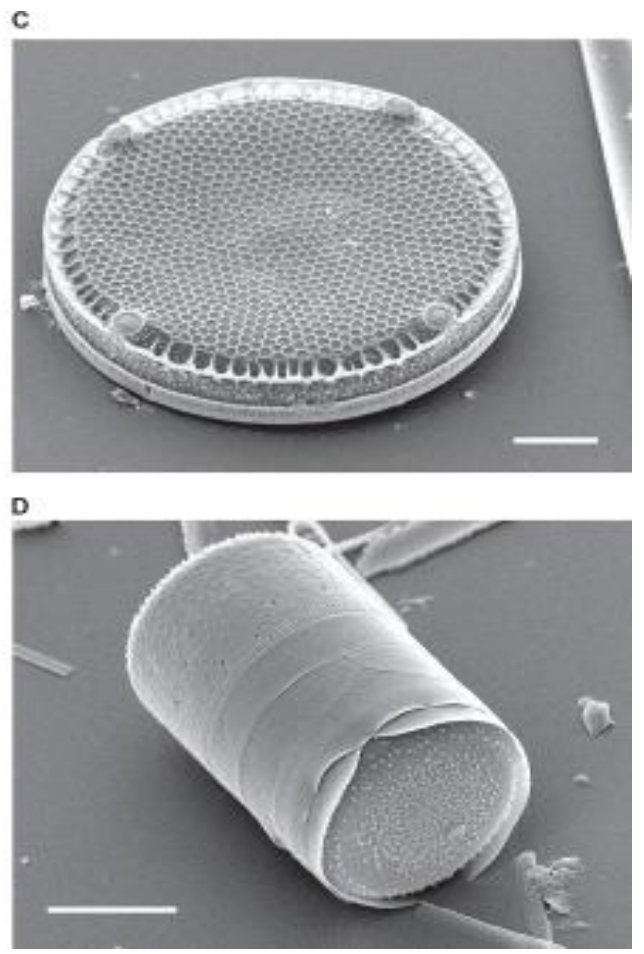

Figure 7. Scanning Electron Micrographs of Diatoms [8 Slika 7. Elektronska slika diatoma [8]

Keratin is one of the most utilized non mineralized hard materials, for example, it makes up the baleen of whales, much of the shells of turtles, reptile scales, rhinoceros horns, and human nails and hair. Keratin is a protein which forms helical chains cross linked with amino acids. This 
structure can be flexible very rigid depending on the degree of cross-linking, a trait which allows keratin to perform so many functions in the animal kingdom. Two forms of the keratin protein exist, alpha-keratin which is found in mammals and have a coiled structure, and beta-keratin which is found in birds and reptiles, is harder, and has a twisted sheet structure. Though not as hard as the mineralized materials discussed earlier keratin is much tougher [9].

\section{CONCLUSION}

With the exception of the medical field, biological hard materials as they exist in nature are not particularly useful in an engineering sense. Instead the value of biological materials lies in what we can learn from them. The techniques used by living creatures is essentially a nanotechnology, one that precedes that adopted by humans by millions of years, and exceeds the best of modern technology. These natural manufacturing techniques contain the secret to revolutionary materials such as the diatom drug delivery system, or a dense ceramic with a microstructure specially tailored for its application. The first steps to unlocking these secrets of the natural world are already being taken. It is humbling to consider that a few cells can produce nanostructures more reliably and for a microfraction of the cost in comparison to the best nanotechnology has to offer.

\section{REFERENCES}

[1] A.Matsushiro, T. Miyashita (2004) Evolution of hard-tissue mineralization: comparison of the inner skeletal system and the outer shell system, Journal of Bone and Mineral Metabolism, 22, 163-169.

[2] J.Currey (1984) The Mechanical Adaptations of Bone, Princeton: Princeton Univerity Press.

[3] P.Clarkson (2008) Dem Bones, Dem Important Bones. The Science Creative Quarterly 3.-Sept 2007, 5.-April 2008, 10.-Dec 2008.

[4] D.Poitout (2004) Biomechanics and Biomaterials in Orthopedics., Springer.

[5] K.M.Wilbur, A.S.M. Saleuddin (1983) The Mollusca Vol 4 Part 1. New York: Academic Press, 1983.

[6] J.R.Meyer (2006) The Exoskeleton. External Anatomy. 17. 02. 2006. NC State University. 10 Dec 2008

[7] Ch.Zurzolo, Ch.Bowler (2001) Exploring Bioinorganic Pattern Formation in Diatoms. A Story of Polarized Tracking, Plant Physiology 127, 1339-1345.

[8] J.Bradbury J (2004) Nature's Nanotechnologists: Unveiling the Secrets of Diatoms, PLoS Biol, 2(10), 306-314.

[9] L.Kreplak, J.Doucet, P.Dumas, F.Briki (2004) New Aspects of the a-Helix to b-Sheet Transition in Stretched Hard a-Keratin Fibers, Biophysical Journal, 87, 640-647.

\section{IZVOD}

\section{BIOLOŠKI TVRDI MATERIJALI}

Koristeći samo prekursore koji su uobičajeno dostupni u okruženju na temperaturama okoline, razvili su se materijali sa složenošću i svojstvima o kojima današnji inženjeri mogu samo sanjati u proizvodnji. Prilikom ispitivanja bioloških tvrdih materijala vršeno je upoređivanje mehaničkih osobina bioloških materijala sa materijalima izrađenim od strane čoveka i može se reći da su materijali izrađeni od strane čoveka na neki način superiorniji. Biologija nikada nije došla do materijala čvrstog kao silicijum karbida, ili jake kao čelik, ali da bi se napravila ova poređenja moraju se ozbiljno shvatati materijali prisutni u prirodnom svetu.

Biologija čvrstih materijala je izuzetno kompleksna, nije teška po inženjerskim standardima, i svoju ulogu bolje organizuje u organizmu nego bilo koji sintetički materijali.

Ključne reči: biološki tvrdi materijali, mehaničke osobine, sintetički materijali, inženjerski standardi.

Naučni rad

Rad primljen: 25. 06. 2017.

Rad korigovan: 08. 09. 2017.

Rad prihvaćen: 22. 09. 2017.

Rad je dostupan na sajtu: www.idk.org.rs/casopis

(C) 2017 Authors. Published by Inženjersko društvo za koroziju. This article is an open access article distributed under the terms and conditions of the Creative Commons Attribution 4.0 International license (https://creativecommons.org/licenses/by/4.0/) 